\title{
Şema Başa Çıkma Biçimleri Ölçeği Türkçe Formunun Geçerlik ve Güvenirlik Çalışması1 ${ }^{1}$
}

\author{
DOI: 10.26466/opus. 805108 \\ $*$ \\ Ferhat Bayoğlu* - Baki Duy ** \\ * Dr., Anadolu Üniversitesi, Eğitim Fakültesi, Eskişehir/Türkiye \\ E-Posta: fbayoglu@anadolu.edu.tr \\ ORCID: 0000-0002-1925-396X \\ ${ }^{* *}$ Doç. Dr., Anadolu Üniversitesi, Eğitim Fakültesi, Eskişehir/Türkiye \\ E-Posta: bakiduy@gmail.com \\ ORCID: $\underline{0000-0002-6082-8518}$
}

\section{Öz}

Bu çalışmada Şema Başa Çıkma Biçimleri Ölçeği'nin (Schema Coping Questionnaire-SCQ) Türkçe formunun geçerlik ve güvenirliğinin incelenmesi amaçlanmıştır. Çalışmanın katılımcıları, 2017-2018 akademik yılında Anadolu Üniversitesi'nin örgün lisans programlarına devam eden 367 üniversite öğrencisinden oluşmaktadır. Veri toplama araçları olarak Demografik Bilgi Formu, Şema Başa Çıkma Ölçeği (SCQ) ve Başa Çıkma Tutumlarını Değerlendirme Ölçeği (COPE) kullanılmıştır. Veriler SPSS 24.00 programı ile birlikte LISREL 9.1 programı kullanılarak analiz edilmiştir. Ölçeğin geçerliğini değerlendirmek amacıyla, doğrulayıcı faktör analizi ile birlikte benzer ölçek geçerliği; güvenirliği belirlemek için ise, Cronbach Alfa iç tutarlılık Katsayısı ve testi yarılama (eşdeğer yarılar) yöntemleri kullanılmıştır. Ölçeğin yapı geçerliği için gerçekleştirilen doğrulayıcı faktör analizinde, ölçeğin üç boyutlu (kaçınma, teslim ve aşırı telafi) ve 12 maddeden oluşan modelinin iyi uyum gösterdiği belirlenmiştir ( $x^{2} / d f=2.23$, RMSEA=.058, CFI= .94, NNFI=.94, AGFI=.93, SRMR=.054). Ölçeğin iç tutarlık katsayıları, kaçınma alt boyutunda .67 , teslim alt boyutunda .73, aşırı telafi alt boyutunda 69 ve ölçeğin bütünü için ise, .78 olarak bulunmuştur. Ölçeğin madde toplam korelasyon katsayıları .24 ile .58 arasında yer almaktadır. Çalı̧̧manın bulgularına göre, Şema Başa Çıkma Biçimleri Ölçeği'nin Türkçe formunun şema başa çıkma biçimlerini değerlendirmek amacıyla kullamılabilecek geçerli ve güvenilir bir ölçme aracı olduğu söylenebilir.

Anahtar Kelimeler: Şema terapi, Başa çıkma biçimleri, Üniversite öğrencileri, Geçerlik, Güvenirlik

\footnotetext{
${ }^{1}$ Bu çalışma Doç. Dr. Baki Duy danışmalığında Dr. Ferhat Bayoğlu tarafından hazırlanan doktora tezinden üretilmiştir.
} 


\title{
A Study About The Validity and Reliability of The Turkish Version of Schema Coping Questionnaire
}

\begin{abstract}
This study aims to investigate the validity and reliability of the Turkish version of the Schema Coping Questionnaire. The study participants consist of 367 university students, attended at Anadolu University's formal undergraduate programs in the 2017-2018 academic year. Demographic Information Form, Schema Coping Questionnaire and Coping Orientation to Problems Experienced (COPE) Inventory were used as data collection tools. The data were analyzed using the LISREL 9.1 program together with the SPSS 24.00 software. Confirmatory factor analysis and similar scale validity was used to evaluate the validity of the scale, and Cronbach's alpha internal consistency coefficient and split-half test (equivalent halves) methods were used to determine the reliability. In the confirmatory factor analysis performed for the construct validity of the scale, it was determined that the threedimensional 12-item model of the scale (avoidance, surrender, and overcompensation) has a good fit. The internal consistency coefficients of the scale were .67 in the avoidance sub-scale, .73 in the surrender sub-scale, .69 in the overcompensation sub-scale, and .78 for the scale total. Item-total correlation coefficients of the scale were in the range of .24 and .58. According to the findings of the study, it can be stated that the Turkish form of the Schema Coping Questionnaire is a valid and reliable measurement tool that can be used to evaluate schema coping styles.
\end{abstract}

Keywords: Schema therapy, Coping styles, University students, Validity, Reliability 


\section{Giriş}

Gündelik yaşam içerisinde insanlar zaman zaman güç veya sıkıntı verici olaylar ve durumlar yaşamakta bir diğer ifadeyle, başa çıkmakta zorlandığı güçlükler ve yaşantılara maruz kalabilmektedirler. Bireyler, sorunlariyla farklı destek sistemleri ve kaynakları ile başa çkmaya çalışmakta ve bu anlamda aslında sorunlar karşısında birbirlerinden çok farklı olacak şekilde başa çıkma davranışlarını ortaya koymaktadırlar. Başa çıkma, genel anlamiyla var olan bir sorun ve stres anında mevcut sorunun çözümüne yönelik yapılan davranış biçimlerini ifade etmektedir (Wong ve Wong, 2006).

Lazarus ve Folkman (1984) başa çımayı, bireylerin algılamış oldukları, kaynaklarını aşan belli içsel ve dışsal zorlanmalarını; kontrol altına almak, azaltmak veya tolere etmek için işe koşulan, sürekli farklılaşan davranışsal veya bilişsel çabalar olarak tanımlamaktadır. Diğer bir ifadeyle, başa çıkma tepkileri, stresli bir durumu, zarar veya tehditi önleme ya da azaltma çabaları olarak ifade edilmektedir (Carver ve Connor-Smith, 2010). Başa çıkma davranışları ve yöntemleri, geleneksel olarak sorun odaklı, duygu odaklı, işlevsel ve işlevsellikten uzak gibi kategorilere ayrılmıştır (Wong ve Wong, 2006). İ̧̧levsel başa çıkma, aktif ve içsel başa çıkmayı içerip, destek arayışında, somut eylemlerde bulunarak veya olası çözümlere yansıyarak sorunlarla başa çıkma girişimlerini ifade etmektedir. İşlevsel olmayan başa çıkma ise, geri çekilmeyi içerir ve inkar veya baskıya, duyguları kontrol etmeye ve kaderci bir tutum sergilemeyi işaret etmektedir (Seiffge-Krenke, 1993).

Gerginlikten kurtulmak, çatışmadan kaçınmak veya geri çekilmek (örneğin, zor, rahatsız edici veya hoş olmayan insanlardan, durumlardan veya uyaranlardan kaçınmak gibi) olumsuz sonuçlara yol açması beklenen negatif başa çıma yöntemleri olarak belirtilmiştir (Colomba, Santiago ve Rossello, 1999). Araştırmalar eylem odaklı başa çıkmanın, pozitif psikolojik sonuçlar ile güçlü bir şekilde ilişkili olduğunu (Monzai vd., 2015; Nelis vd., 2011); inkârcı, kaçınmacı ve duygu odaklı olumsuz yöntemlerin ise, olumsuz ruh sağlığıyla ilişkili olma eğiliminde olduğunu göstermektedir (Folkman vd., 1986; Lazarus ve Folkman, 1984; Mackay, Charles, Kemp ve Heckhausen, 2011; Seiffge-Krenke, 1993). Üniversite öğrencileriyle yapılan bir araştırmada (Pritchard, Wilson ve Yamnitz, 2007), olumsuz başa çıkma yöntemleri ve mükemmeliyetçiliğin, olumsuz ruhsal ve fiziksel sağlık için; iyimserlik ve benlik 
saygısının ise, olumlu fiziksel ve ruhsal sağlık sonuçları için anlamlı birer yordayıcı olduğunu ortaya koymuştur. Benzer şekilde, duygusal farkındalık ve başa çıkma becerileri olarak duygusal yeterliliğin daha olumlu gelişim ve sağlıklı ilişkilerle ilişkili olduğu vurgulanmaktadır (Zaff vd., 2016). Aktif başa çıkma yöntemleri, mevcut koşulları iyileştirme ve problem çözme açısından da daha avantajlı görülmektedir (Carver ve Connor-Smith, 2010).

Bland, Melton, Welle ve Bigham (2012), üniversite öğrencileri arasında yüksek ya da düşük stres toleransı ile yaşam tarzı alışkanlıklarını ve baş etme yöntemlerini incelemiş oldukları çalışmalarında, öğencilerin sıklıkla akademik stresin etkilerini şiddetlendirebilecek uyumsuz başa çıkma yöntemleri ve yașam tarzı alışkanlıkları kullandıklarını ve yüksek öğrenim kurumlarında öğrenciler arasında stresle baş etmenin daha uyumlu biçimlerini teşvik eden müdahalelere ihtiyaç duyulduğunu ileri sürmektedirler. Bu anlamda, bireylerin problem çözebilme becerilerini geliştirme ve sorunlarıyla işlevsel bir biçimde başa çıkabilmelerine yardımcı olma anlamında profesyonel yardım hizmetlerinin önemli bir işlevinin olduğu düşünülmektedir. Diğer taraftan hem yardım alma hem de baş etme davranışlarının yaşantılarla öğrenildiği ve özellikle de genç bireylerin başta ebeveynleri olmak üzere çevrelerindeki diğer yetişkinlerin tutumları ile birlikte baş etme stillerini gözlemleyerek içselleştirdikleri de vurgulanmaktadır (Frydenberg, 1997'den akt. Barker vd., 2005; Yöntem ve İlhan, 2019). Bu bağlamda son yıllarda işlevsel olmayan başa çıkma biçimleri açısından, erken dönem olumsuz yaşantılarla ilişkilendirilen ve uyum bozucu etkileri olduğu düşünülen şema başa çıma biçimlerinin ön plana çıtı̆̆ı̆ görülmektedir.

Genel anlamıyla zor veya tehditkâr durumlar karşısında bireyler tarafindan gösterilen başa çıkma çabaları ve sergilenen tepkiler olarak değerlendirilen başa çıkma biçimleri (Jacob, van Genderen ve Seebauer, 2015), farklı kuramlar açısından ele alınmış ve her kuram kendi perspektifinden bu kavrama yaklaşmıştır. Bu kuramlardan biri de Şema Terapi modelidir. Bu yaklaşım açısından, erken dönem uyum bozucu şemalar ile işlevsel olmayan şema başa çıkma biçimlerinin birleşimi, ruhsal rahatsılılkların kavramsal çekirdeğini oluşturmaktadır. Bu modele göre, erken dönem uyum bozucu şemaların zamanla bireylerin hayatlarında önemli alanlarda bozulmalara ve de sorunlar yaşamalarına kaynaklık ettiği ve bu sorunlar karşısında da genellikle işlevsel olmayan başa çıma davranışlarının sergilendiği belirtilmektedir (van Vreeswijk, Broarsen ve Nadort, 2012). Şema başa çıkma biçimleri, hayatta 
kalma stratejileri veya zor ya da tehdit edici durumlarıyla "başa çıkma tarzları" olarak da adlandırılmaktadır (Bernstein, 2005). Bu anlamıla uyumsuz şema başa çıkma biçimlerinin, bireylerin sorun yaşamalarına neden olan erken dönem yaşantılarıyla nasıl baş ettiğini ve bu şemaların bireylerin yaşantılarında nasıl görünür olduğunu betimlemek için kullanılan bir kavram olduğu ifade edilebilir.

Şema teslimi, şema kaçınması ve şema aşırı telafisi olarak üç farklı şekilde tanımlanan işlevsel olmayan bu başa çıkma biçimlerinden şema teslimi başa çıkma biçimi, kişinin şemalarına boyun eğmesini ve onları onaylayan bir biçimde hareket etmesini ifade ederken; şema kaçınması, kişinin şemalarını aktive edecek kişi, olay, ortam ve yaşantılardan kaçınmasını; şemanın aşırı telafisi ise, kişinin sahip olduğu şemalarının tam tersini yapmasını ifade etmektedir (Rafaeli vd., 2011). Başa çıkma biçimleri, şema terapinin temel öğelerinden birini oluşturmakta ve insanların çocukluk yaşantılarında istenmeyen durumlarla mücadele etmek için sergilemiş oldukları davranış biçimleri olarak ele alınmaktadır. Bu durum aslında, bireylerin rahatsız edici durumlara karşı, 'şu an ben ne yapıyorum?' sorusuna verilen yanıtları ifade edilmektedir (Young ve Klosko, 1993).

Şema başa çıkma biçimleri, yaşanılan sorunla etkin bir şekilde baş etmeyi sağlayan işlevsel başa çıkma tepkilerini yansıtmamaktadır. Aksine bu başa çıkma tepkileri, sorunlara çözüm üretmekten öte, yardım alma önündeki bir engel olarak tanımlanmakta ve şema terapi modeli açısından uyum bozucu başa çıma davranışları olarak değerlendirilmektedir (Rafaeli, Bernstein ve Young, 2011). Şema başa çıkma biçimleri, bir ölçüde bireylerin şemalarıyla mücadele etmesine yardımcı oluyor olarak gözükse de aslında bu başa çıkma yöntemleri iyileştirici ve de uzun vadede işlevsel olarak değerlendirilmemektedir. Bu kapsamda, şema başa çıkma biçimleri, şemaların devamlılık sürecindeki önemli öğeler olarak rol oynamaktadırlar (Young, Klosko ve Weishaar, 2003). Sonuç olarak, şema başa çıkma biçimleri, bireylerin kısa süreli olarak güvende hissetmelerini sağlamış olsa bile kaçınma davranışında olduğu gibi uzun vadede var olan sorunların devam etmesine neden olmaktadır (Rafaeli vd., 2011).

Bireyler şemalarının tetiklenmesiyle, diğer bir ifadeyle olumsuz duyguları harekete geçiren erken dönem uyum bozucu şemalarıyla çok farklı şekillerde başa çıkmaya çalışmaktadırlar. Ortaya konan tüm bu çabalar belki bir aşa- 
maya kadar işe yarar olarak değerlendirilmektedir; ancak bu davranış biçimleri uzun vadede bireylerin hayatlarını daha da zorlaştırarak, bir anlamda yaşam kalitesini düşürmekte ve işlevselliği olumsuz olarak etkileyebilmektedir (Young ve Klosko, 1993). Bununla birlikte, bu uyumsuz baş etme biçimlerinin, bireylerin uyum bozucu şemalarının devamlılığına neden olduğu da vurgulanmaktadır (Rafaeli vd., 2011; van Vreeswijk vd., 2012). Bu anlamıla, bu baş etme biçimlerinin, uzun vadede uyum bozucu şemaları kuvvetlendiren bir etkiye sahip olduğu belirtilmekle beraber, sürecin olumlu anlamda değişmesi için de aslında bir engelleyici işlevi olduğu ifade edilmektedir (Young, 1999). Bu bağlamda değerlendirildiğinde, sorunların bireyler açısından görmezden gelinmesi veya kısa vadeli ve geçici olarak çözülmüş olduğu algisı, bu bireylerin sorunlarıyla etkin bir şekilde baş etmeleri veya gereksinim duydukları profesyonel yardımı almaları önünde engelleyici bir etken olarak da rol oynayabilmektedir. Bu anlamda, şema başa çıkma biçimleri olarak kaçınma, teslim ve aşırı telafi gibi işlevsel olmayan başa çıkma biçimlerinin, bireylerin sorunlar karşısındaki tutumlarıyla ilişkisinden hareketle, psikolojik yardım alma sürecinde önemli bir değişken olabileceği düşünülmektedir.

Başa çıkma biçimleri ile psikolojik yardım alma tutumu arasındaki ilişkiye yönelik yapılan araştırmalarda (Rickwood, Deane, Wilson ve Ciarrochi 2005; Sheu ve Sedlacek, 2002; Sheu ve Sedlacek, 2004; Türküm, 2001) etkin ve işlevsel başa çıkma becerilerini kullanan bireylerin psikolojik yardım almaya yönelik tutumlarının daha olumlu; işlevsel olmayan başa çıkma yöntemlerine sahip olanların ise, yardım alma tutumlarının daha olumsuz olduğu dikkati çekmektedir. Başa çıkma becerileri ile psikolojik yardım almaya ilişkin tutumlarının incelendiği araştırmalarda, işlevsel olmayan başa çıma becerileri sergileyen kişilerin; problem çözme becerisi, uzman yardımına başvurma ve sosyal destek alma gibi daha işlevsel başa çıkma becerileri ortaya koyanlara göre, psikolojik yardım almaya ilişkin daha olumsuz tutumlara sahip olduğu görülmektedir (Ercan, 2010; Radziwon, 2009; Ward-Ciesielski, Limowski, Kreper ve McDermott, 2019).

Genel olarak değerlendirilecek olursa, şema başa çıkma biçimleri, mevcut sorunu çözme ve ortadan kaldırmak yerine, kaçınma davranışında olduğu gibi sorunların sürmesine neden olacak şekilde işlevsiz/uyumsuz (maladaptive) şema başa çıma biçimlerini kullanmayı ifade etmektedir. Bu doğrultuda, sorun yaşayan bireyler tarafından profesyonel bir yardım almak veya etkin başa çıkma becerilerini kullanmak yerine tercih edilen işlevsel olmayan 
bu şema başa çıkma biçimleri ile psikolojik yardım alma tutumu ve davranışları arasında bir ilişkinin varlığından söz edilebilir. Diğer taraftan, uygun müdahale yöntemleri ile bireylerin sorunlar karşısında uyumsuz başa çıkma biçimleri yerine daha işlevsel başa çıkma davranışlarında bulunmaları da söz konusu olabilmektedir. Bu bağlamda, bireylerin sahip oldukları bu başa çıkma biçimlerinin belirlenmesinin önemi ortaya çıkmaktadır. Bireylerin sorunlar karşısındaki baş etme biçimlerinin farkında olmaları hem sorunlar karşısındaki mücadeleleri hem de yardım alma sürecindeki müdahaleler aç1sında önemli olduğundan, bu başa çıkma biçimlerinin belirlenip ortaya çıkarılmasının önemli olduğu düşünülmektedir. Bireylerin tetikleyici olumsuz yaşam olayları karşısında ortaya koymuş oldukları bu işlevsel olmayan/uyum bozucu başa çıkma biçimlerini belirlemek için de bir ölçme aracına gereksinim duyulmaktadır.

İlgili alanyazın incelendiğinde, özellikle işlevsel olmayan, uyum bozucu olarak nitelendirilen başa çıkma biçimlerini belirlemeye yönelik farklı ölçme araçlarının mevcut olduğu görülmektedir. Young-Rygh Kaçınma Ölçeği (Karaosmanoğlu, Soygüt ve Kabul, 2011) ve Young Telafi ölçeği (Soygüt, Karaosmanoğlu ve Çakır, 2009) bu ölçme araçlarının örneklerini oluşturmaktadır. Ancak, Şema Başa Çıkma Ölçeği'nin, (van Vreeswijk ve Broersen, 2006) şema başa çıkma biçimlerinin ölçülmesine yönelik geliştirilmiş olan ve Türkçe'ye uyarlaması da daha önce gerçekleştirilmiş olan bu ölçme araçlarından; şema başa çıkma biçimlerini ayrı ayrı olarak değil de üç tür başa çıkma biçimini tek bir ölçme aracı içerisinde bir arada ölçebilecek nitelikte olması açısından daha işlevsel olduğu değerlendirilmektedir. Bununla birlikte, ölçeğin diğer şema başa çıkma ölçeklerine göre nispeten daha az madde içermesi de kullanışlılık açısından da daha işlevsel olduğuyla ifade edilebilir. Bu bilgiler doğrultusunda bu çalışmada, Şema Başa Çıkma Ölçeği'nin (ŞBÇÖ) Türkçe formunun geçerlik ve güvenirliğinin incelenmesi amaçlanmıştır.

\section{Yöntem}

Çalışmanın bu bölümünde; araştırmanın çalışma grubu, verilerin toplanması, veri toplama araçları, işlem süreci ve verilerin analizine ilişkin ayrıntılı bilgiler yer almaktadır. 


\section{Çalışma Grubu}

ŞBÇÖ'nün geçerlik ve güvenirlik çalışması kapsamında veriler, Anadolu Üniversitesinin farklı örgün lisans programlarına devam eden üniversite öğrencilerinden toplanmıştır. Türkçe çevirisi ve dil geçerliliği yapılan ölçeğin doğrulayıc faktör analizi (DFA) Anadolu Üniversitesinin farklı fakültelerinde öğrenim gören 367 (\%57.2 kadın, \%42.8 erkek) üniversite öğrencisi üzerinden gerçekleştirilmiştir. Bununla birlikte, ölçeğin test-tekrar güvenirliği için veriler 58 (\%53.4 kadın, \%46.6 erkek), ölçüt bağıntılı geçerlilik kapsamında ise 47 (\%38.3 kadın, \%61.7 erkek) lisans öğrencisinden elde edilmiştir. Araştırmaya katılan katılımcıların yaş aralığı 18-29 arasında ve yaş ortalaması 22.15'tir $(S s \pm 3.02)$.

Katılımcıların öğrenim gördükleri fakülteleri dikkate alındığında en çok katılımcının eğitim fakültesinden ( $n=102)$ ve sinıf düzeyine göre ise, birinci sınıftan ( $n=104)$ oldukları görülmektedir. Genel olarak, fakültelere ve sınıf düzeyine göre katılımcıların dengeli bir dağılıma sahip oldukları söylenebilir.

\section{Verilerin Toplanması}

Verilerin toplanması sürecinde, öncelikle araştırmada kullanılacak olan ölçme araçlarının kullanım izinlerinin alınması planlanmıştır. Bu kapsamda, ölçme araçlarıyla ilgili izin almak amacıyla ilgili yazar/yazarlara e-posta yolu ile ulaşım sağlanmış ve gerekli izinler alınmıştır. Verilerin toplanabilmesi için Anadolu Üniversitesi'nden de etik ve yasal izinler alınmıştır. Veri toplama sürecinde gerek araştırmanın amaç ve içeriğine ilişkin bilgilerin yer aldığı gerekse tüm katılımcıların araştırmaya gönüllü katılımlarını sağlamak için hazırlanan bilgilendirilmiş onam formu da veri toplama aracına eklenmiştir. Verilerin toplanması amacıyla, ölçme araçları ile birlikte kişisel bilgi formu da kullanılmıştır. Belirtilen ölçme araçlarıyla ilgili verilerin toplanmasının, ortalama 10-15 dakika sürdüğü gözlenmiştir.

\section{Veri Toplama Araçları}

Araştırmada verilerin toplanmasında; Kişisel Bilgi Formu ile birlikte Şema Başa Çıkma Ölçeği (ŞBÇÖ) ve Başa Çıkma Tutumlarmı Değerlendirme Ölçeği (COPE) kullanılmıştır. Bu veri toplama araçlarıyla ilgili detaylı bilgilere aşağıda yer verilmiştir. 
Kişisel Bilgi Formu: Araştırma kapsamında katılımcların kişisel bilgilerini toplamak ve çalışma grubu hakkında bilgi elde etmek amacıyla, 'Kişisel Bilgi Formu' kullanılmıştır. Bu form, çalışma grubunda yer alan öğrencilerin cinsiyet, sınıf, yaş ve bulundukları lisans programının belirlenmesi amacıyla araştırmacılar tarafından oluşturulmuştur.

Başa Çıkma Tutumların Değerlendirme Ölçeği (COPE): COPE, bireylerin s1kıntı veren durumlar ve sorunlar karşısında sergiledikleri başa çıkma tutumlarını belirlemek amaciyla geliştirilen ve 15 alt boyut ile toplamda 60 maddeden oluşan bir ölçektir (Carver, Scheier ve Weintraub, 1989). Her alt ölçek dörder maddeden oluşmaktadır. Ölçek 4'lü Likert türünde derecelendirilmiş bir ölçektir. Ölçeğin alt boyutları arasında işlevsel olan başa çıkma biçimleri ile birlikte işlevsel olmayan başa çıkma biçimleri de yer almaktadır. Ölçeğin maddeleri; 1 ("Asla böyle yapmam") ile 4 "Çoğunlukla böyle yaparım" arasında bir puanlamaya sahiptir. Ölçekte olumsuz puanlanan bir madde bulunmamaktadır. Alt ölçeklerden alınan yüksek puanlar, bireylerin bu başa çıkma biçimlerine yönelik eğilimlerinin yüksek olduğu; düşük puanlar ise, bu başa çıkma biçimlerine yönelik daha düşük tutuma sahip olunduğu anlamina gelmektedir.

COPE'nin Türkçe formunun psikometrik özelliklerine ilişkin çalışma Ağargün, Beşiroğlu, Kıran, Özer ve Kaya (2005) tarafından gerçekleştirilmiştir. Ölçeğin iç tutarlık katsayısı 0.79 ve alt ölçeklere ait puanların COPE toplam puanıyla ilişkisi pozitif yönde ve anlamlı olarak bulunmuştur. Yine ölçeğe ait tek tek madde puanları pozitif yönde ve ileri düzeyde test-tekrar test güvenirliği göstermiştir. Çalışmanın sonuçları, Başa Çıkma Tutumlarını Değerlendirme Ölçeği'nin sahip olduğu bu psikometrik özellikleri ile Türk kültüründe başa çıkma tutumlarını değerlendirmek amacıyla kullanılabilecek geçerli ve güvenilir bir ölçme aracı olduğunu göstermektedir.

Şema Başa Çıkma Ölçeği : Şema Başa Çıkma Ölçeği (ŞBÇÖ), şema başa çıma yöntemlerini (şema kaçınması, şema aşırı telafisi ve şema teslimi) değerlendirmek için geliştirilmiş bir ölçme aracıdır. ŞBÇÖ, 16 maddeden oluşmakta olup 3 alt boyuta sahiptir. Bu alt boyutlar; şema kaçınması, şema teslimi ve şemanın aşırı telafisi şeklinde tanımlanmıştır. Yapılan analizler sonucunda, her üç alt ölçeğin de iç tutarlılığı yeterli bulunmuştur (Cronbach Alfa katsa- 
yıSı aralığı=.72-.76). Ölçek 1-6 arasında Likert türü bir derecelendirmeye sahiptir. Ölçekten alınan puanların değerlendirilmesiyle ilgili olarak; alt ölçek toplam puanlarının yüksek olması, tanımlanan şema başa çıkma davranışının arttı̆̆ına işaret etmektedir (van Vreeswijk ve Broersen, 2006).

Şema Başa Çıkma Ölçeği'nin, şema başa çıkma biçimlerini ayrı olarak değil de üç tür başa çıkma biçimini tek bir ölçme aracı olarak içermesi açısından daha işlevsel olduğu değerlendirilmektedir. Bununla birlikte, ölçeğin diğer şema başa çıkma ölçeklerine göre nispeten daha az madde içermesi de kullanışlılık açısından bir avantaj olarak ifade edilebilir. Bu doğrultuda, araştırma kapsamında ŞBÇÖ'nün Türkçeye uyarlama çalışması gerçekleştirilmiştir. Ölçme aracının Türkçeye uyarlanmasına yönelik gerçekleştirilen geçerlik ve güvenirlik çalışmalarına ilişkin süreç aşağıda yer almaktadır.

\section{İşlem Süreci}

ŞBÇÖ'nün Türkçeye uyarlanması sürecinde öncelikle ölçme aracı için gerekli olan izinler alındıktan sonra, ölçeğin Türkçeye çevirisine geçilmiştir. Ölçeğin Türkçeye çeviri çalışması iki aşamalı olarak gerçekleştirilmiştir. Bu kapsamda ilk olarak hem Türkçeye hem de İngilizceye hâkim Psikolojik Danışma ve Rehberlik (PDR) alanından iki akademisyen, iki doktorant ve Yabancı Diller bölümünden bir alan uzmanı tarafından ölçekte yer alan maddelerin birbirlerinden bağımsız olarak çevirisi yapılmıştır. Çevirileri yapılan ölçek maddelerine ilişkin Şema Terapi alanında kuramsal ve süpervizyon eğitimine sahip olan üç farklı uzmanın da görüşlerine başvurulmuştur. Bu aşamada gerçekleştirilen çevirilerin karşılaştırılması yapılmış ve ilgili ölçek maddelerini en iyi yansıttığı düşünülen çeviriler belirlenmiştir. Daha sonra, araştırmacılar tarafından ölçeğin Türkçe formunun son halinde uzlaşılmış ve ölçeğe dil geçerliği çalışması için son şekli verilmiştir.

Son şekli verilen ölçek ile birlikte orijinal ölçeğin iki hafta aralıklarla uygulanması, Eğitim Fakültesi İngilizce Öğretmenliği bölümü 4. sınıfta öğrenim gören 44 lisans öğrencisi ile gerçekleştirilmiştir. İki ölçek arasındaki ilişkiye yönelik gerçekleştirilen analize ilişkin bulgular, ölçeğin iki formu arasında yüksek düzeyde pozitif anlamlı bir ilişki olduğunu göstermiştir ( $\mathrm{r}=.86, \mathrm{p}<$. 001). Bu sonuca göre, ölçeğin Türkçe ve İngilizce olan formunun eşdeğer olduğu kabul edilmiş ve ölçek uyarlama kapsamında bir sonraki aşamaya geçilmesine karar verilmiştir. 


\section{Verilerin Analizi}

Çalışmada verilerin analizi sürecinde öncelikle betimleyici istatistiklerden yararlanılmıştır. Eksik yanlış veya hatalı cevaplar veren katılımclar belirlenmiştir. Bu doğrultuda, 23 katılımcı araştırma dişında tutulmuş ve analize kalan 344 veri ile devam edilmiştir.

Araştırma sürecinde öncelikle ölçme aracının uyarlama sürecine ilişkin analizler yapılmıştır. Bu çerçevede katılımcıların demografik özelliklerine ilişkin betimsel istatistiklerden, ölçme araçlarının geçerlik ve güvenirlik değerleri için ise Doğrulayıcı Faktör Analizi (DFA) ve Cronbach Alfa $(\alpha)$ iç tutarlık katsayısı analizlerinden yararlanılmıştır.

Çalışma kapsamında, veriler SPSS 24.00 paket program ile birlikte LISREL 9.1 programı (Jöreskog ve Sörbom, 2006) kullanılarak analiz edilmiştir.

\section{Bulgular}

\section{Yapı geçerliği (Doğrulayıcı faktör analizi)}

ŞBÇÖ'nün model uyumu Doğrulayıcı Faktör Analizi yöntemi ile test edilmiştir. Bu doğrultuda, orijinal ölçekte olduğu gibi 16 madde ve üç faktörlü yap1 test edilmiş ve gerçekleştirilen DFA sonuçları Şekil 1 ve Şekil 2'de verilmiştir.

Yapılan doğrulayıcı faktör analiz ile 16 maddelik üç faktörlü modelinin uyum indeksleri de incelenmiş ve analizler sonucunda ortaya çıkan uyum indekslerine ise Tablo 1'de yer verilmiştir. 


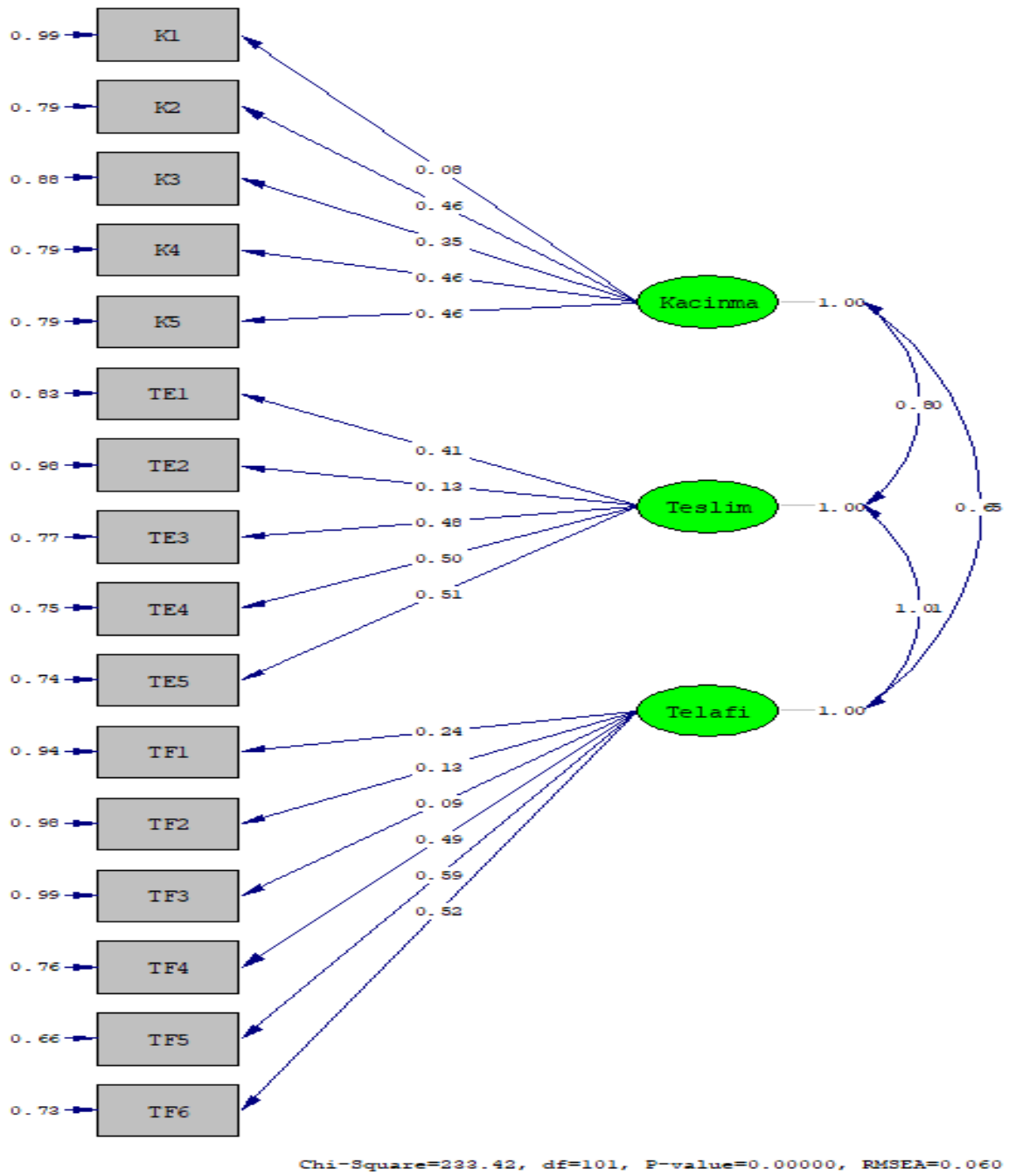

Şekil 1. ŞBÇÖ doğrulayıcı faktör analizi standart yük değerleri

K: Şema kaçınması TE: Şema teslimi TF: Şema telafisi 


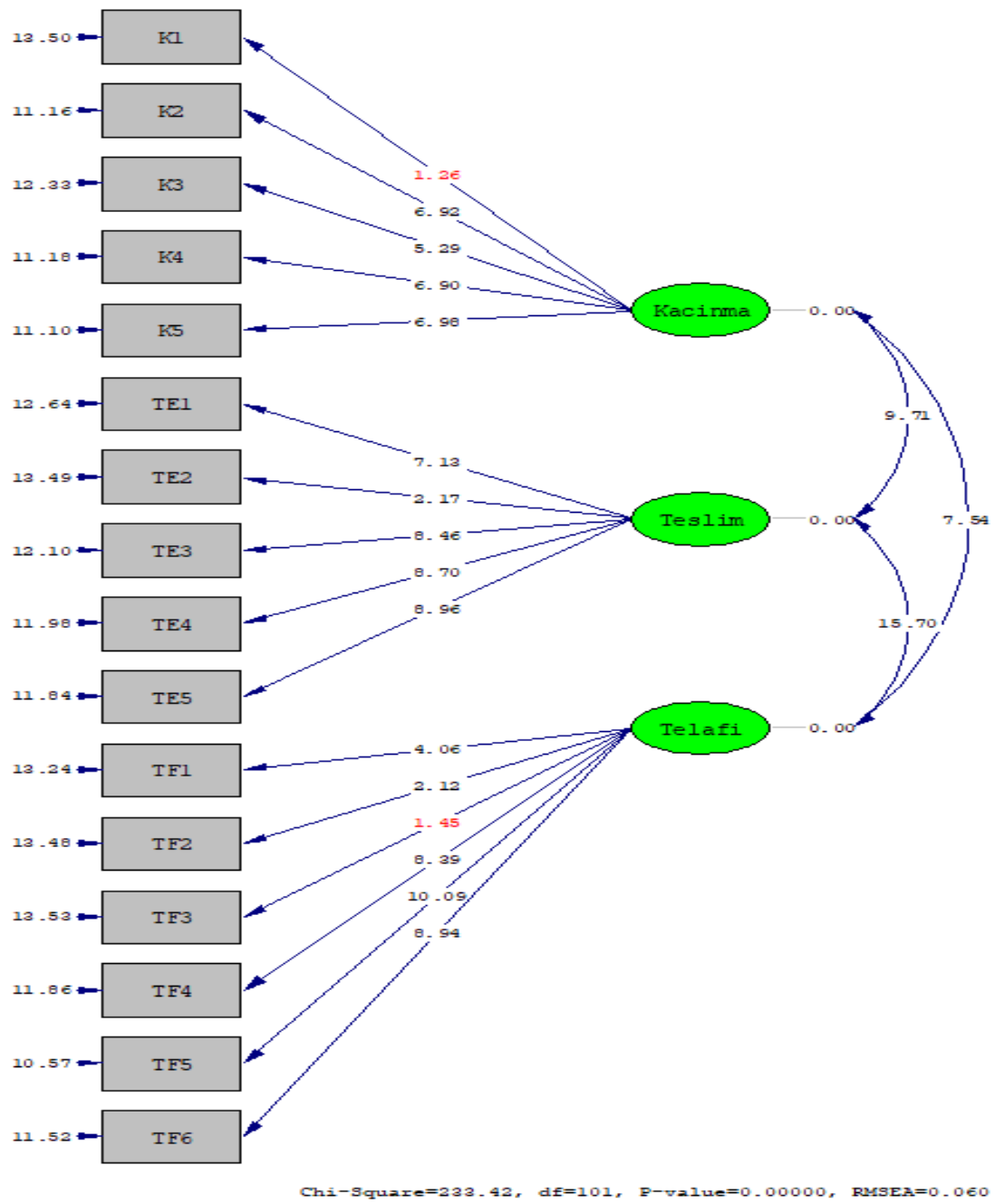

Şekil 2. ŞBÇÖ doğrulayıcı faktör analizi standart yük değerleri

K: Şema kaçınması TE: Şema teslimi TF: Şema telafisi 
Tablo 1. ŞBÇÖ'nün birinci düzey doğrulayıcı faktör analizine ilişkin bulgular

\begin{tabular}{lcccl}
\hline İndeks & $\begin{array}{l}\text { Mükemmel } \\
\text { Uyum Ölçütü }\end{array}$ & $\begin{array}{l}\text { KabulEdilebilir } \\
\text { Uyum Ölçütü }\end{array}$ & $\begin{array}{l}\text { Araştırma } \\
\text { Bulgusu }\end{array}$ & Kaynak \\
\hline $\mathbf{X}^{2} /$ df & $\leq 3$ & $\leq 5$ & 2.31 & Tabachnick ve Fidell (2013) \\
\hline RMSEA & $\leq .05$ & $\leq .08$ & .06 & Hu ve Bentler (1999); Sümer (2000) \\
\hline SRMR & $\leq .05$ & $\leq .08$ & .07 & Brown (2006); Bryne (1994) \\
\hline CFI & $\geq .95$ & $\geq .90$ & .91 & Hu ve Bentler (1999); Sümer (2000) \\
\hline NNFI & $\geq .95$ & $\geq .90$ & .90 & Schumacker ve Lomax (1996) \\
\hline AGFI & $\geq .90$ & $\geq .85$ & .89 & Marcholudis ve Schumacher (2001) \\
\hline
\end{tabular}

Modelin istatistiksel olarak uygunluğunu değerlendirmek için bazı uyum değerleri referans olarak alınmaktadır. Bu çalışmada modelin uyumunu belirlemek amaciyla sıklıkla kullanılan, ki-karenin serbestlik derecesine bölünmesiyle elde edilen değer olan $X^{2} / d f$ değerinden ve Yaklaşık Hataların Ortalama Karekökü (RMSEA), Standardize Edilmiş Artık Ortalamaların Karekökü (SRMR), Karşılaştırmalı Uyum İndeksi (CFI), Normlaştırılmamış Uyum İndeksi (NNFI) ve Düzeltilmiş Uyum İyiliği İndeksi (AGFI) ölçütlerinden yararlanılmıştır.

Model uyumunda $X^{2} / s d$ değerinin 5 'ten küçük olması kabul edilebilir olarak görülürken, $3^{\prime}$ den küçük olması ise modelin mükemmel uyumuna işaret etmektedir (Tabachnick ve Fidell, 2013). Bununla birlikte, bir modelin iyi uyum göstermesi için; RMSEA değerinin ise .08 'den küçük olması beklenmektedir, ancak bu değerin .05 'ten küçük olması mükemmel uyumu göstermektedir (Hu ve Bentler, 1998; Sümer 2000). Ayrıca, CFI ve NNFI değerlerinin .90'ın üzerinde çıkması kabul edilebilir olduğu, .95 ile 1.00 arasında olması ise modelin mükemmel uyum gösterdiği anlamına gelmektedir (Hu ve Bentler, 1999; Schumacker ve Lomax, 1996). Bu bilgiler doğrultusunda, Tablo 1 'deki sonuçlar incelendiğinde, uyum indekslerinin genel olarak kabul edilebilir sınırlar içerisinde yer aldığı görülmektedir.

Bununla birlikte, Şekil 1 ve Şekil 2'deki diyagramları incelendiğinde, yapılan ölçüm modeli sonucunda, ölçme modelinde yer alan göstergelere ait t değerlerinin 1.26 ile 10.09 arasında; madde faktör yüklerinin ise, .09 ile .59 arasında değiştiği belirlenmiş ve bu değerlerden bazılarının .05 düzeyinde anlamlı olmadıkları tespit edilmiştir.

Diyagramlar ayrıntılı olarak incelendiğinde, anlamlı olmayan $t$ değerlerine sahip maddeler (K1: 'Acı, üzüntü ve öfke duygusundan kaçınmaya çalışırım', TF3: 'Bir şeyleri başkalarının yardımını almaksızın kendi başıma yapmayı tercih ederim') ile birlikte düşük faktör yük değerlerine ve yüksek hata varyanslarına 
sahip olan maddelerin (TE2: 'Başkalarının düşüncelerinin, duygularmm ve eylemlerinin iç yüzünü iyi anlayabildiğime inanıyorum', TF2: 'Tükendiğim anlarda bile çok çalışırım') olduğu görülmüsştür. Dolayısıyla analiz sonucunda, ölçeğin kaçınma alt boyutu (K1) ve teslim alt boyutundan (TE2) birer madde; telafi alt boyutundan ise, iki madde (TF2) ve (TF3) olmak üzere toplam dört maddenin uzman görüşü de alınarak ölçme aracından çıkarılmasına karar verilmiş ve ölçüm modeli kalan maddeler üzerinden yeniden test edilmiştir.

Ölçeğin 12 madde ve üç faktörden oluşan yapısının model uyumu doğrulayıc faktör analizi ile incelenmiş ve analize ilişkin bulgulara Şekil 3 ve Şekil $4^{\prime}$ te yer verilmiştir. Test edilen ölçüm modeline ilişkin uyum iyiliği değerleri ise, Tablo 2' de verilmiştir.

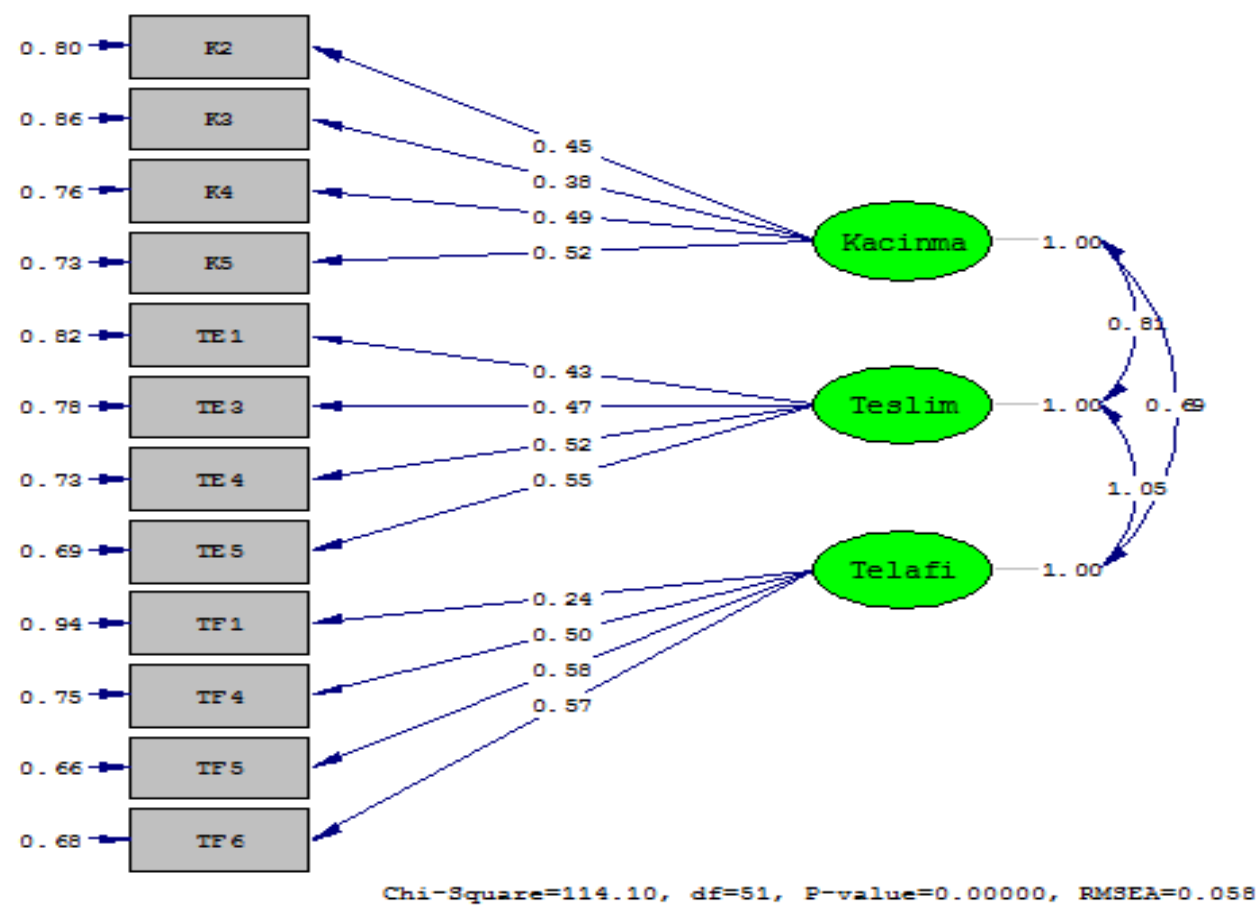

Şekil 3. ŞBÇÖÖ 3 boyutlu model doğrulayıcı faktör analizi standart yük değerleri

K: Şema kaçınması TE: Şema teslimi TF: Şema telafisi 


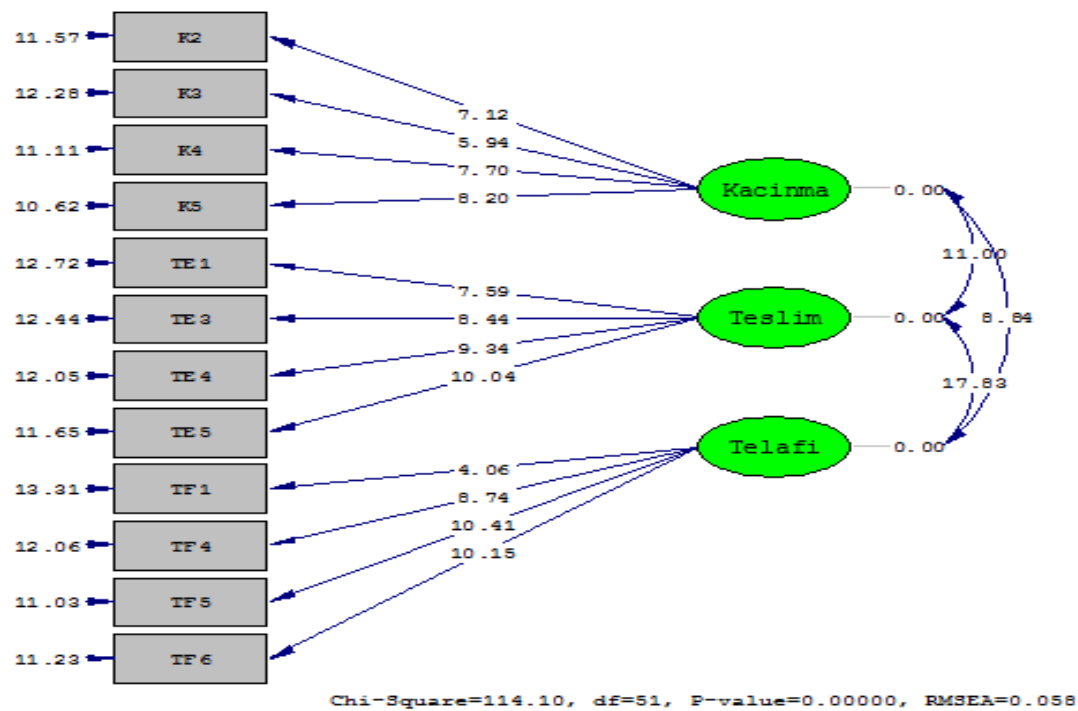

Şekil 4. ŞBÇÖ 3 boyutlu model doğrulayıcı faktör analizi t değerleri

K: Şema kaçınması TE: Şema teslimi TF: Şema telafisi

Tablo 2. ŞBÇÖ'nün doğrulayıcı faktör analizine ilişkin bulgular

\begin{tabular}{lccll}
\hline İndeks & $\begin{array}{l}\text { Mükemmel } \\
\text { Uyum Ölçütü }\end{array}$ & $\begin{array}{l}\text { KabulEdilebilir } \\
\text { Uyum Ölçütü }\end{array}$ & $\begin{array}{l}\text { Araştırma } \\
\text { Bulgusu }\end{array}$ & Kaynak \\
\hline $\mathbf{X}^{2} /$ df & $\leq 3$ & $\leq 5$ & 2.23 & Tabachnick ve Fidell (2013) \\
\hline RMSEA & $\leq .05$ & $\leq .08$ & .06 & Hu ve Bentler (1999); Sümer (2000) \\
\hline SRMR & $\leq .05$ & $\leq .08$ & .05 & Brown (2006); Bryne (1994) \\
\hline CFI & $\geq .95$ & $\geq .90$ & .94 & Hu ve Bentler (1999); Sümer (2000) \\
\hline NNFI & $\geq .95$ & $\geq .90$ & .94 & Schumacker ve Lomax (1996) \\
\hline AGFI & $\geq .90$ & $\geq .85$ & .93 & Marcholudis ve Schumacher (2001) \\
\hline
\end{tabular}

Yapılan doğrulayıcı faktör analizi ile ŞBÇÖ'nün Türkçe formunun üç faktörlü modelinin uyum indeksleri incelenmiştir. DFA sonuçlarına göre, 12 madde ve üç alt boyuttan oluşan Şema Başa Çıkma Ölçeği'nin uyum indekslerinin kabul edilebilir sınırlar içerisinde olduğu görülmüştür.

\section{Benzer Ölçek Geçerliği}

ŞBÇÖ'nün benzer ölçek geçerliğini değerlendirmek amaciyla Carver, Scheier ve Weintraub (1989) tarafından geliştirilen ve Ağargün ve diğerleri (2005) tarafından Türkçeye uyarlaması yapılan Başa Çıkma Tutumları Ölçeği'nin (COPE) işlevsel olmayan başa çıkma alt ölçeği kullanılmıştır. Her iki ölçme aracının alt boyutlarına ilişkin korelasyonlar, Pearson Momentler Çarpımı 
Korelasyon Katsayısı ile hesaplanmıştır. Analize ilişkin sonuçlar Tablo 3'de verilmiştir.

Tablo 3. ŞBÇÖ ile COPE arasındaki korelasyonlar

\begin{tabular}{|c|c|c|c|c|c|}
\hline & 1 & 2 & 3 & 4 & 5 \\
\hline 1. ŞBÇÖ-Kaçnma & - & & & & \\
\hline 2. ŞBÇÖ-Teslim & $.50^{*}$ & - & & & \\
\hline 3. ŞBÇÖ-Aşır Telafi & $.49^{\prime \prime}$ & $.58^{\prime \prime}$ & - & & \\
\hline 4. Toplam ŞBÇÖ & $.82^{*}$ & $.83^{*}$ & $.83^{*}$ & - & \\
\hline 5. COPE-İslevsel olm. & $.39^{*}$ & $.49^{*}$ & $.62^{* *}$ & $.56^{*}$ & - \\
\hline
\end{tabular}

Tablo 3 incelendiğinde, ŞBÇÖ ile COPE ölçeğinin alt boyutlarından işlevsel olmayan başa çıkma boyutu arasında anlamlı bir ilişki olduğu görülmektedir $(r=.56, p<.05)$. COPE alt boyutlarından olan işlevsel olmayan başa çıkma boyutu, ŞBÇÖ'nün alt boyutları olan kaçınma $(r=.38, p<.05)$, teslim $(r=.49$, $p<.05)$ ve aşırı telafi $(r=.62, p<.01)$ ile anlamlı bir ilişki göstermektedir. İşlevsel olmayan başa çıkma alt boyutunda puan arttıkça, bireylerin uyum bozucu başa çıkma biçimlerini daha çok tercih ettiği ifade edilebilir. Bu durumun ŞBÇÖ'nün alt boyutları olan kaçınma, teslim ve aşırı telafi ile de ilişkili olduğu görülmektedir.

\section{Güvenirlik Analizi Sonuçlarn}

ŞBÇÖ'nün güvenirliği değerlendirmek amac ile Cronbach Alfa iç tutarlılık katsayısı ve testi yarılama (eşdeğer yarılar) yöntemleri kullanılmıştır. Gerçekleştirilen analizlere ilişkin bulgular Tablo 4'te verilmiştir.

Tablo 4. ŞBÇÖ'nün iç tutarlık ve iki yarn güvenirlik yöntemiyle hesaplanan güvenirlik katsayılarn

\begin{tabular}{lll}
\hline Boyutlar & İç Tutarlılık & Testi Yarılama Güvenirliği \\
\hline ŞBÇÖ-Kaçınma & .67 & .63 \\
\hline ŞBÇÖ-Teslim & .73 & .74 \\
\hline ŞBÇÖ-Aşırı Telafi & .69 & .71 \\
\hline ŞBÇÖ-Toplam & .78 & .78 \\
\hline
\end{tabular}

\section{Sonuç ve Öneriler}

Bu çalışmada van Vreeswijk ve Broersen (2006) tarafından bireylerin olumsuz yaşam olayları karşısında ortaya koymuş oldukları işlevsel olmayan/uyum bozucu başa çıkma biçimlerini belirlemek amacıyla geliştirilmiş 
olan Şema Başa Çıkma Ölçeği'nin (ŞBÇÖ) Türkçe Formunun, üniversite öğrencilerinden oluşan bir çalışma grubu üzerinden geçerlik ve güvenirlik analizleri gerçekleştirilmiştir.

Ölçeğin orijinal formu 16 madde ve üç boyuttan oluşmaktadır. Ölçeğin bu mevcut haliyle gerçekleştirilen doğrulayıc faktör analizi sonucunda, ölçme modelinde yer alan göstergelere ait $t$ değerlerinin 1.26 ile 10.09 arasında, madde faktör yüklerinin ise .09 ile .59 arasında değiştiği belirlenmiş ve bu değerlerden bazılarının da .05 düzeyinde anlamlı olmadıkları tespit edilmiştir. Modele ilişkin gerçekleştirilen analiz sonuçları ayrıntılı olarak incelendiğinde, anlamlı olmayan $\mathrm{t}$ değerlerine sahip maddeler (K1: 'Acl, üzüntü ve öfke duygusundan kaçınmaya çalısırım', TF3: 'Bir şeyleri başkalarının yardımını almaksızın kendi başıma yapmayı tercih ederim') ile birlikte düşük faktör yük değerlerine ve yüksek hata varyanslarına sahip olan maddelerin (TE2: 'Başkalarmın düşüncelerinin, duygularının ve eylemlerinin iç yüzünü iyi anlayabildiğgime inantyorum', TF2: 'Tükendiğim anlarda bile çok çalş̧ırm') yer aldığı görülmüştür. Dolayısıyla analiz sonucunda, ölçeğin kaçınma alt boyutu (K1) ve teslim alt boyutundan (TE2) birer madde; telafi alt boyutundan ise iki madde (TF2) ve (TF3) olmak üzere toplam dört maddenin çıkarılmasına karar verilmiştir. Ölçekte yer alan ilgili bu maddelerin, şema sürdürücü işlevsel olmayan başa çıkma biçimlerinden farklı olarak katılımcılar tarafından daha olumlu ve istenilen bir davranış şekli olarak algılandığı değerlendirilmektedir. Bir anlamda, ilgili bu maddelerin kültürel olarak toplumumuzda olumlu sayılabilecek davranış kalıpları olarak kabul gördüğü ve bu haliyle de kültürümüzde geçerli olmayan şema başa çıkma biçimlerini yansıttı̆̆ı söylenebilir. Bu çerçevede, Şema Terapi alanında kuramsal ve süpervizyon eğitimine sahip olan alan uzmanlarının görüşleri de alınmış ve bu doğrultuda söz konusu maddeler ölçme aracından çıkarılarak ölçüm modeli kalan maddeler ile tekrardan test edilmiştir.

Ölçeğin, 12 madde ve üç faktörlü yapısının model uyumu doğrulayıcı faktör analizi ile yeniden incelenmiş ve $t$ değerleri ve faktör yükleri ile ölçüm modeline ilişkin uyum iyiliği değerlerinin kabul edilebilir sınırlar içerisinde olduğu görülmüştür. Ölçeğin uyum iyiliği değerlerinin orijinal ölçekteki haliyle 16 madde ve şu boyutlu yapıdan oluşan modelinde kabul edilebilir s1nırların altında olduğu gözlenmekle beraber, analizler sürecinde ölçekten çıkarılan maddeler sonrasında gerçekleştirilen 12 maddelik üç boyutlu mode- 
linde ise, bu uyum değerlerinin anlamlı bir şekilde iyileştiği ve kabul edilebilir ve hatta mükemmel uyum değerleri içerisinde yer aldığı gözlenmektedir $\left(x^{2} / d f=2.23, R M S E A=.058, C F I=.94, N N F I=.94, A G F I=.93, S R M R=.054\right)$. Diğer taraftan, uyum indeksinde yer alan bazı uyum değerlerinin örneklem say1sına karşı duyarlı olduğu ve bu örneklem büyüklüğünden etkilenebildiği belirtilmektedir (Çokluk, Şekercioğlu ve Büyüköztürk, 2012; Hu ve Bentler, 1999). Bu kapsamda, ölçek bu mevcut haliyle araştırmacılar tarafından kullanılabilir; ancak farklı gruplarda ve daha büyük örneklemler üzerinde ölçeğin uyum indeklerine yeniden bakılabilir.

Bütün bunlarla birlikte, ölçeğin güvenirliği için hesaplanan iç tutarlık güvenirlik katsayıları ise; kaçınma alt boyutu için .67, teslim alt boyutu için .73, aşırı telafi alt boyutu için .69 ve ölçeğin bütünü için ise .78 olarak bulunmuştur. Ölçeğin güvenirliği için belirlenen bu iç tutarlık katsayılarının, özgün ölçeğin gerçekleştirilen analiz sonuçlarında da kabul edilebilecek sınırlar içerisinde yer aldığı gözlenmekte (Cronbach Alfa katsayısı aralığı= .72-.76), bu durum mevcut araştırmada da benzer bir yapıda değerler göstermektedir. Ancak, özgün ölçeğe göre, ŞBÇÖ'ün hem bazı alt ölçek hem de ölçeğin bütün olarak iç tutarlık katsayıları bazında nispeten daha yüksek olduğu, ancak yine de değerlerin iç tutarlık açısından yeterli olmadığı değerlendirilmektedir. Bu durumun, ölçek maddelerinde farklı alt boyutlarda olsa bile yer alan bazı maddelerdeki ifadelerin birbirine yakın anlamlar içermesinden kaynaklı olabileceği düşünülmektedir. Diğer taraftan, bu sonuçlar özellikle ölçme aracının dayandığı Şema modeli açısından değerlendirildiğinde ise, erken dönem uyum bozucu şemaların psikolojik rahatsızlıklara kaynaklık ettiği ve olumsuz yaşam olayları karşısında tetiklenen bu şemalara karşı başa çıkma tepkilerinin gösterildiği yaklaşımına dayalı olarak geliştirilmiş olan bu ölçme araçlarının daha çok psikolojik rahatsızlıklar ile ilişkisi göz önünde bulunduralabilir. Bu anlamda, özellikle 'normal' olarak kabul edilen diğer bir ifadeyle, genel örneklem yerine daha çok 'hasta' veya bir psikolojik rahatsızlı̆̆a sahip olduğu düşünülen şema yaklaşımına dayalı klinik örneklem üzerinde gerçekleştirilen çalışmalarda, bu ölçme araçlarının daha geçerli ve güvenilir sonuçlar verebildiğine ilişkin olan araştırma sonuçları (Rijkeboer ve van den Bergh, 2006; Rijkeboer ve Lobbestael, 2016; Roelofs, Muris ve Lobbestael, 2015; van Vlierberghe, Braet, Bosmans, Rosseel ve Bögels, 2010) söz konusudur. Nitekim, şema başa çıkma biçimleri ölçeğinin hem klinik örneklem ve 
genel örneklem üzerinde geçerlik ve güvenirlik çalışmasının ergenler üzerinde gerçekleştirdiği bir çalışmanın sonuçlarına göre, başa çıkma ölçeğinin klinik örneklemdeki iç tutarlık katsayılarının genel örneklemdekine göre daha yüksek değerlere sahip olduğu ortaya konulmuştur (van Wijk-Herbink vd., 2017).

Araştırmanın çalışma grubu, üniversite öğrencilerinden oluşturmakla birlikte, daha çok önceden bir psikolojik yardım deneyimine sahip olmayan kişiler katılımclarının önemli bir bölümünü oluşturmaktadır. Bu anlamda, özellikle şema başa çıkma biçimleri açısından değerlendirildiğinde, daha güvenilir sonuçlara ulaşmak amacıyla, ileride yapılabilecek araştırmalar daha çok üniversite psikolojik danışma ve rehberlik merkezleri, mediko-sosyal merkezleri veya üniversite hastaneleri gibi ruh sağlığı hizmeti veren bu merkezlerinden yardım alan bireyler ile gerçekleştirilebilir. Diğer taraftan, öğrencilerin başa çıkma biçimlerini daha iyi yansıtmak ve örneklem çeşitliliğini sağlamak adına, ilgili ölçme aracı kullanılarak farklı üniversiteleri kapsayacak şekilde araştırmanın daha büyük bir örneklem üzerinde hem yardım alan hem de yardım almayan öğrencileri de kapsayacak ve/veya karşılaştıracak bir yapıda da gerçekleştirilmesi söz konusu olabilir.

İlgili alanyazında şema başa çıkma biçimlerini değerlendirmek için kullanılan farklı ölçme araçları (Karaosmanoğlu vd., 2011; Soygüt, vd., 2009) olsa da Şema Başa Çıkma Ölçeği'nin, bu ölçeklerden şema başa çıkma biçimlerini aşırı telafi ölçeği veya kaçınma ölçeği şeklinde ayrı ayrı olarak değil de şema teslimi, şema kaçınması ve şema aşırı telafisi olarak üç tür başa çıkma biçimini tek bir ölçme aracı içerisinde ölçebilecek nitelikte olması açısından daha işlevsel olduğu düşünülmektedir. Bununla birlikte, 3 alt boyut ve toplamda 12 maddeden oluşan ŞBÇÖ'nin diğer ilgili ölçme araçlarına nispeten daha az madde içermesiyle de ölçeğin kullanışlılık açısından da işlevsel olduğu değerlendirilmektedir.

Araştırma doğrultusunda gerçekleştirilen geçerlik ve güvenirlik analizlerinden elde edilen sonuçlar, Şema Başa Çıkma Ölçeği Türkçe Formunun, bireylerin kaçınma, teslim ve telafi olarak üç farklı başa çıkma biçimini değerlendirebilecek bir yapıda olduğunu göstermektedir. Her ne kadar bu bulgulara göre, Şema Başa Çıkma Biçimleri Ölçeği, bireylerin uyum bozucu şema başa çıkma biçimlerini bir bütün olarak değerlendirebilecek geçerli ve güvenilir bir ölçme aracı olsa da bu ölçme aracının Türk kültüründeki bireylerin başa çıkma biçimlerini tam olarak yansıtmadığı söylenebilir. Bu doğrultuda, 
bundan sonra yapılacak olan çalışmalarda, bireylerin şema başa çıkma biçimlerini belirlemek amacıyla, Türk kültürüne daha uygun bir ölçme aracı kullanmak adına, şema başa çıkma biçimlerine yönelik kültürümüze özgü bir ölçme aracı geliştirmenin önemli bir gereksinimi karşılayacağı düşünülmektedir. 


\title{
EXTENDED ABSTRACT
}

\section{A Study About The Validity and Reliability of The Turkish Version of Schema Coping Questionnaire}

\author{
Ferhat Bayoğlu - Baki Duy \\ Anadolu University
}

Coping refers to the behaviors aimed at solving a problem that exists in a general sense or the current problem at the time of a stress. In other words, coping is defined as constantly changing cognitive and behavioral efforts to control, reduce or tolerate certain internal and external demands and conflicts that perceived by individuals and exceed their individual resources (Lazarus and Folkman, 1984). Coping behaviors and methods have traditionally been divided into problem-oriented, emotion-oriented, functional, and non-functional categories (Wong and Wong, 2006).

Coping strategies, which are generally considered as coping efforts and reactions shown by individuals in the face of difficult or threatening situations (Jacob, van Genderen, and Seebauer, 2015), have been considered from the perspectives of different theories, and each theory has approached this concept from its own perspective. One of these theories is the Schema Therapy model. This model states that schemas that disrupt adjustment in the early period lead to deterioration and problems in important areas in individuals' lives over time, and individuals often exhibit dysfunctional coping behaviors in the face of these problems (van Vreeswijk, Broarsen, and Nadort, 2012).

Although schema coping styles appear to help individuals to some extent deal with their schemas, in fact, these coping methods are not considered functional and therapeutic in the long term (Young, Klosko ve Weishaar, 2003). In this context, schema coping styles play an important role in the continuity process of schemas. As a result, schema coping styles cause problems to continue in the long term, as in avoidance behavior, even if individuals feel safe for a short time (Rafaeli vd., 2011). 
In general, it is possible to state that there is a relationship between attitudes and behaviors of getting psychological help and these non-functional schema coping styles, which are preferred by individuals who experience problems, instead of getting a professional help or using effecting coping skills. On the other hand, with appropriate intervention methods, it may also be possible for individuals to engage in more functional coping behaviors rather than maladaptive coping styles in the face of problems. In this context, it is of importance to determine these coping styles that individuals have. It is believed that it is important to identify and reveal these coping styles since it is important for individuals to be aware of their cope styles in the face of problems, both in terms of interventions to be made when getting psychological help and their efforts against problems. Thus, a measurement tool is needed to identify these non-functional/maladaptive coping styles that individuals exhibit in the face of negative, triggering life events.

A review of the relevant literature shows that there are various measurement tools available to identify maladaptive coping styles. The Young-Rygh Avoidance Scale (Karaosmanoğlu, Soygüt and Kabul, 2011) and the Young Compensation Scale (Soygüt, Karaosmanoğlu, and Çakır, 2009) are examples of these measurement tools. However, the Schema Coping Questionnaire (van Vreeswijk and Broersen, 2006) is considered to be more functional in terms of being able to measure three schema coping styles in a single measurement tool, not separately. However, the fact that the scale contains relatively fewer items than other schema coping scales can also be more functional in terms of usefulness. In accordance with this information, this study aims to investigate the validity and reliability of the Turkish form of the Schema Coping Questionnaire (SCQ).

Within the scope of the validity and reliability study of SCQ, the data were collected from university students attending various formal undergraduate programs of Anadolu University. After its Turkish translation and linguistic validity, the confirmatory factor analysis (CFA) of the scale was conducted on 367 (57.2\% female, $42.8 \%$ male) university students studying at different faculties of Anadolu University.

Along with the Personal Information Form, the Schema Coping Questionnaire (SCQ) and Coping Orientation to Problems Experienced (COPE) were used in the collection of study data. 
During the research process, first of all, analyses were made about the adaptation of the measurement tool. In this context, regarding the descriptive statistics on the demographic characteristics of the participants, the Confirmatory Factor Analysis (CFA) and Cronbach's Alpha $(\alpha)$ internal consistency coefficient analyses were used for the validity and reliability of the measurement tool.

Within the scope of the study, the data were analyzed using the LISREL 9.1 program (Jöreskog \& Sörbom, 2006) together with the SPSS 24.00 software.

The model fitness of the SCQ was tested by the method of Confirmatory Factor Analysis (CFA). In this regard, the 16-item and three-factor structure was tested, as in the original scale, and the goodness of fit indices of the model were examined by the CFA results.

According to the analysis of the results through CFA, the $t$ values of the indicators in the measurement model were found to vary between 1.26 and 10.09 , and the factor loadings were found to vary in the range of .09 and .59, and it was found that some of them were not significant at the 05 level. However, it is observed that the fit indexes for the model fall within generally acceptable limits. As a result of the analysis, items with non-significant $t$ values, as well as items with low factor load values and high error variances were examined and it was decided to remove a total of four items from the measurement tool in line with the expert opinion, and the measurement model was retested over the remaining items.

Model fitness of the 12-item three-factor structure of the scale was examined by confirmatory factor analysis, and the results of the analysis and the goodness of fit values were re-evaluated. By means of the confirmatory factor analysis, the fitness indices of the three-factor model of the Turkish form of the SCQ were examined. According to the CFA results, the fitness indices of the schema coping questionnaire, consisting of 12 items and three sub-dimensions, were found to be within acceptable limits $\left(x^{2} / \mathrm{df}=2.23\right.$, RMSEA $=.058$, $\mathrm{CFI}=.94, \mathrm{NNFI}=.94, \mathrm{AGFI}=.93$, SRMR $=.054$ ).

$\mathrm{T}$ values of the scale were in the range of 4.06 to 10.41 (see Figure 3), and the item factor loads were in the range of .24 to .58 (see Figure 4). The internal consistency coefficients of the scale were .67 in the avoidance sub-scale, .73 in the surrender sub-scale, .69 in the overcompensation sub-scale, and .78 for the scale total. According to the findings of the study, it can be stated that the 
Turkish form of the Schema Coping Questionnaire is a valid and reliable measurement tool that can be used to evaluate schema coping styles.

analyses of the Turkish form of the Schema Coping Questionnaire (SCQ), developed by van Vreeswijk and Broersen (2006) to identify non-functional/maladaptive coping styles that individuals exhibit in the face of negative life events, were carried out through a study group of university students. In this context, the model fitness of the SCQ was tested by the method of confirmatory factor analysis. The results of the reliability and validity analyses performed in accordance with the research show that the 12-item threefactor Turkish version of the Schema Coping Questionnaire can evaluate the avoidance, surrender and compensation coping styles in a single structure $\left(x^{2} / \mathrm{df}=2.23, \mathrm{RMSEA}=.058, \mathrm{CFI}=.94, \mathrm{NNFI}=.94, \mathrm{AGFI}=.93, \mathrm{SRMR}=.054\right)$. The fact that SCQ contains relatively fewer items than other relevant measurement tools indicates that it can be more functional in terms of usefulness.

It is observed that these internal consistency coefficients for the reliability of the scale are within acceptable limits (Cronbach alpha coefficient range= .67-.78), especially in terms of the schema approach. It was found that the internal consistency coefficients of the schema coping styles questionnaire in the clinical sample had higher values than in the general sample.

Although the psychometric characteristics of the Schema Coping Questionnaire are acceptable, it can be stated that the scale does not fully reflect the coping styles of individuals in Turkish culture. In this regard, in future studies, it is believed that developing a measurement tool specific to Turkish culture for the schema coping styles will meet an important need in order to use a measurement tool more suitable for Turkish culture.

\section{Kaynakça / References}

Ağargün, M. Y., Beşiroğlu, L., Kıran, Ü. K., Özer, Ö. A., ve Kara, H. (2005). COPE (Basa Çıkma Tutumlarını Değerlendirme Ölçeği): Psikometrik özelliklere iliskin bir ön çalışma. Anadolu Psikiyatri Dergisi, 6(4), 221-226.

Barker, G., Olukoya, A., ve Aggleton, P. (2015). Young people, social support and help-seeking. International Journal of Adolescent Medicine and Health, 17(4), 315336. doi:10.1515/IJAMH.2005.17.4.315

Bland, H. W., Melton, B. F., Welle, P., ve Bigham, L. (2012). Stress tolerance: New challenges for millennial college students. College Student Journal, 46(2), 362-376. 
Bernstein, D. P. (2005). Cognitive therapy for clients with personality disorders and comorbid Axis I psychopathology.J. Reich (Ed.), Personality disorders: Current research and treatments içinde (s. 154-159). New York: Routledge.

Carver, C. S. ve Connor-Smith, J. (2010). Personality and coping. Annual Review of Psychology, 61(1), 679-704.

Colomba, M. V., Santiago, E. S., ve Rosselló, J. (1999). Coping strategies and depression in Puerto Rican adolescents: An exploratory study. Cultural Diversity and Ethnic Minority Psychology, 5(1), 65-75.

Çokluk, Ö., Şekercioğlu, G. ve Büyüköztürk, Ş. (2012). Sosyal bilimler için çok değişkenli istatistik: SPSS ve LISREL uygulamalarn (Vol. 2). Ankara: Pegem Akademi.

Ercan, L. E. (2010). An analysis of the relationship between attitudes towards seeking psychological help and problem solving among university students. Procedia-Social and Behavioral Sciences, 2(2), 1814-1819.

Folkman, S., Lazarus, R. S., Gruen, R. J., ve DeLongis, A. (1986). Appraisal, coping, health status, and psychological symptoms. Journal of Personality and Social Psychology, 50(3), 571-579.

Hu, L.T. ve Bentler, P. M. (1999). Cutoff criteria for fit indices in covariance structure analysis. Structural Equation Modeling: A multidisciplinary Journal, 6(1), 1-55.

Jacob, G., Van Genderen, H., ve Seebauer, L. (2014). Breaking negative thinking patterns: A schema therapy self-help and support book. UK: John Wiley \& Sons.

Jöreskog, K. G. ve Sörbom, D. (2013). LISREL 9.1 for Windows [Computer software]. Lincolnwood, IL: Scientific Software International, Inc.

Karaosmanoğlu, H. A., Soygüt, G., ve Kabul, A. (2013). Psychometric properties of the Turkish Young Compensation Inventory. Clinical Psychology \& Psychotherapy, 20(2), 171-179.

Lazarus, R. S. ve Folkman, S. (1984). Stress, appraisal, and coping. New York: Springer Publishing Company.

Mackay, J., Charles, S. T., Kemp, B., ve Heckhausen, J. (2011). Goal striving and maladaptive coping in adults living with spinal cord injury: Associations with affective well-being. Journal of Aging and Health, 23(1), 158-176.

Marcoulides, G. A. ve Schumacker, R. E. (2001). New developments and techniques in structural equation modeling. London: Lawrence Erlbaum Associates Publishers.

Pritchard M.E., Wilson, G. S., ve Yamnitz, B. (2007). What predicts adjustment among college students? A longitudinal panel study. Journal of American College Health, 56(1), 15-22. 
Radziwon, C. D. (2009). Help-seeking intentions in adolescents: Links to attachment, distress, and coping. Unpublished doctoral dissertation. USA: The Pennsylvania State University.

Rafaeli, E., Bernstein, D. P., ve Young, J. E. (2011). Şema terapi: Ayırıcı özellikler. (Çev: M. Şaşığlu). İstanbul: Psikonet Yayınları.

Rickwood, D. J., Deane, F. P., Wilson, C. J., ve Ciarrochi, J. V. (2005). Young people's help-seeking for mental health problems. Australian e-Journal for the Advancement of Mental Health, 4(3), 218-251.

Rijkeboer, M. M. ve van den Bergh, H. (2006). Multiple group confirmatory factor analysis of the Young Schema-Questionnaire in a Dutch clinical versus nonclinical population. Cognitive Therapy and Research, 30(3), 263-278.

Roelofs, J., Muris, P., ve Lobbestael, J. (2016). Acting and feeling like a vulnerable child, an internalized "bad" parent, or a healthy person: The assessment of schema modes in non-clinical adolescents. Journal of Personality Disorders, 30(4), 469482.

Schumacker, R. E. ve Lomax, R. G. (1996). A beginner's guide to structural equation modeling. Hillsdale, New Jersey, US: Lawrence Erlbaum Associates, Inc.

Seiffge-Krenke, I. (1993). Coping behavior in normal and clinical samples: More similarities than differences? Journal of Adolescence, 16(3), 285-303.

Sheu, H. B. ve Sedlacek, W. E. (2002). Helping-seeking attitudes and coping strategies among college students by race. Paper presented at the Annual Conference of the American Psychological Association, Chicago.

Sheu, H. B. ve Sedlacek, W. E. (2004). An exploratory study of help-seeking attitudes and coping strategies among college students by race and gender. Measurement and Evaluation in Counseling and Development, 37(3), 130-143.

Soygüt, G., Karaosmanoğlu, A. ve Çakır, Z. (2009). Erken dönem uyumsuz şemaların değerlendirilmesi: Young şema ölçeği kısa form-3'ün psikometrik özelliklerine ilişkin bir inceleme. Türk Psikiyatri Dergisi, 20(1), 75-84.

Tabachnick, B. G. ve Fidell, L. S. (2013). Using multivariate statistics (6th ed.), Boston: Allyn and Bacon.

Türküm, A.S. (2001). Stresle başa çıkma biçimi, iyimserlik, bilişsel çarpıtma düzeyleri ve psikolojik yardım almaya ilişskin tutumlar arasındaki ilişkiler: Üniversite ögrencileri üzerinde bir araș,tırma. Anadolu Üniversitesi Sosyal Bilimler Dergisi, 1(2), 1-16.

van Vlierberghe, L., Braet, C., Bosmans, G., Rosseel, Y., ve Bögels, S. (2010). Maladaptive schemas and psychopathology in adolescence: On the utility of young's schema theory in youth. Cognitive Therapy and Research, 34(4), 316-332. 
van Vreeswijk, M. ve Broersen, J. (2006). Schemagerichte therapie in groepen: cognitieve groeps psychotherapie bij persoonlijkheids problematiek. Houten: Bohn Stafleu van Loghum/Springer Media.

van Vreeswijk, M., Broarsen, J., ve Nadort, M. (Eds.). (2012). The wiley-blackwell handbook of schema therapy: Theory, Research, and Practice. UK: A John Wiley \& Sons.

van Wijk-Herbrink, M. F., Roelofs, J., Broers, N. J., Rijkeboer, M. M., Arntz, A., ve Bernstein, D. P. (2018). Validation of schema coping inventory and schema mode inventory in adolescents. Journal of Personality Disorders, 32(2), 220-241.

Ward-Ciesielski, E. F., Limowski, A. R., Kreper, S. N., ve McDermott, M. J. (2019). Relationships between treatment attitudes, psychological symptoms, emotional competence, and help-seeking intentions. Journal of Counseling \& Development, 97(3), 250-259.

Wong, P. T. ve Wong, L. C. J. (2006). Handbook of multicultural perspectives on stress and coping. New York: Springer Science \& Business Media.

Young, J. E. ve Klosko, J. S. (1993). Hayatı yeniden keşfedin. (Çev: S. Kohen ve E. Tuncer) İstanbul: Psikonet Yayınları.

Young, J. E. (1999). Cognitive therapy for personality disorders: A schema-focused approach. Sarasota, FL: Professional Resource Exchange, Inc.

Young, J. E., Klosko, J. S., ve Weishaar, M. E. (2003). Schema therapy: A practitioner's guide. New York: Guilford Press.

Yöntem, M.K. ve İhan, T. (2019). The predictive role of the parenting styles that cause early maladaptive schemas on divorce indicators. Journal of Humanity and Society, 1-9.

Zaff, J. F., Aasland, K., McDermott, E., Carvalho, A., Joseph, P., ve Pufall Jones, E. (2016). Exploring positive youth development among young people who leave school without graduating high school: A focus on social and emotional competencies. Qualitative Psychology, 3(1), 26-45.

\section{Kaynakça Bilgisi / Citation Information}

Bayoğlu, F. ve Duy, B. (2020). Şema başa çıkma biçimleri ölçeği Türkçe formunun geçerlik ve güvenirlik çalışması. OPUS-Uluslararası Toplum Araştırmaları Dergisi, 16(31), 4289-4316. DOI: 10.26466/opus. 805108 